This item was submitted to Loughborough's Research Repository by the author.

Items in Figshare are protected by copyright, with all rights reserved, unless otherwise indicated.

\title{
Ice-cored moraine degradation mapped and quantified using an unmanned aerial vehicle: a case study from a polythermal glacier in Svalbard
}

PLEASE CITE THE PUBLISHED VERSION

http://dx.doi.org/10.1016/j.geomorph.2015.12.019

\section{PUBLISHER}

(C) Elsevier

VERSION

AM (Accepted Manuscript)

\section{PUBLISHER STATEMENT}

This work is made available according to the conditions of the Creative Commons Attribution-NonCommercialNoDerivatives 4.0 International (CC BY-NC-ND 4.0) licence. Full details of this licence are available at: https://creativecommons.org/licenses/by-nc-nd/4.0/

\section{LICENCE}

CC BY-NC-ND 4.0

\section{REPOSITORY RECORD}

Tonkin, Toby N., Nicholas G. Midgely, Simon J. Cook, and David J. Graham. 2019. "Ice-cored Moraine Degradation Mapped and Quantified Using an Unmanned Aerial Vehicle: A Case Study from a Polythermal Glacier in Svalbard". figshare. https://hdl.handle.net/2134/20069. 


\section{Accepted Manuscript}

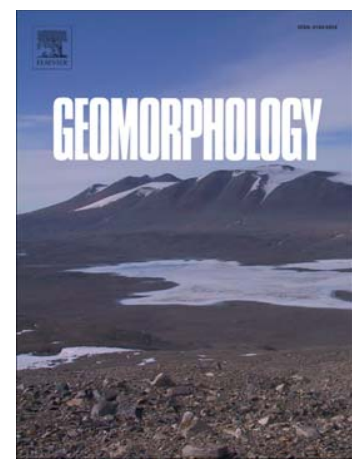

Ice-cored moraine degradation mapped and quantified using an unmanned aerial vehicle: a case study from a polythermal glacier in Svalbard

T.N. Tonkin, N.G. Midgley, S.J. Cook, D.J. Graham

PII:

S0169-555X(15)30239-7

DOI: $\quad$ doi: $10.1016 /$ j.geomorph.2015.12.019

Reference: $\quad$ GEOMOR 5472

To appear in: $\quad$ Geomorphology

Received date: 4 June 2015

Revised date: 23 December 2015

Accepted date: 25 December 2015

Please cite this article as: Tonkin, T.N., Midgley, N.G., Cook, S.J., Graham, D.J., Ice-cored moraine degradation mapped and quantified using an unmanned aerial vehicle: a case study from a polythermal glacier in Svalbard, Geomorphology (2015), doi: 10.1016/j.geomorph.2015.12.019

This is a PDF file of an unedited manuscript that has been accepted for publication. As a service to our customers we are providing this early version of the manuscript. The manuscript will undergo copyediting, typesetting, and review of the resulting proof before it is published in its final form. Please note that during the production process errors may be discovered which could affect the content, and all legal disclaimers that apply to the journal pertain. 
Ice-cored moraine degradation mapped and quantified using an unmanned aerial vehicle: a case study from a polythermal glacier in Svalbard

Tonkin, T.N ${ }^{a},{ }^{*}$, Midgley, N.Ga ${ }^{a}$, Cook, S.J and Graham, D.J ${ }^{\mathrm{c}}$

${ }^{\text {a }}$ School of Animal, Rural and Environmental Sciences, Nottingham Trent University, Brackenhurst Campus, Southwell, Nottinghamshire, UK

b School of Science and the Environment, Manchester Metropolitan University, Manchester, UK

c Polar and Alpine Research Centre, Department of Geography, Loughborough University, Leicestershire, UK

*Corresponding Author: + 441158485257 toby.tonkin@ntu.ac.uk

\section{Keywords}

Structure-from-Motion, deglaciation, geomorphologic change detection, Austre Lovénbreen 


\section{Highlights}

- SfM photogrammetry used to produce topographic data from archive aerial imagery and UAV derived aerial imagery

- Datasets from 2003 and 2014 were compared to report on the deicing of a lateral-frontal ice-cored moraine

- The moraine appears to be de-icing predominantly via downwastage affording the moraine a higher degree of stability

- UAVs and SfM are shown to be useful tools for monitoring environmental change

\section{Abstract}

Ice-cored lateral-frontal moraines are common at the margins of receding high-Arctic valley glaciers, but the preservation potential of these features within the landform record is unclear. Recent climatic amelioration provides an opportunity to study the morphological evolution of these landforms as they de-ice. This is important because high-Arctic glacial landsystems have been used as analogues for formerly glaciated areas in the mid-latitudes. This study uses SfM (Structure-from-Motion) photogrammetry and a combination of archive aerial and UAV (unmanned aerial vehicle) derived imagery to investigate the degradation of an icecored lateral-frontal moraine at Austre Lovénbreen, Svalbard. Across the study area as a whole, over an 11-year period, the average depth of surface lowering was $-1.75 \pm 0.89 \mathrm{~m}$. The frontal sections of the moraine showed low or undetectable rates of change. Spatially variable rates of 
surface lowering are associated with differences in the quantity of buriedice within the structure of the moraine. Morphological change was dominated by surface lowering, with limited field evidence of degradation via back-wastage. This is affording the moraine a greater degree of stability than observed at many other sites in Svalbard, although it is unclear whether the end point will be a fully stabilised ice-cored moraine, in equilibrium with its environment, or an ice-free lateral-frontal moraine complex. Controls on geomorphological change (e.g. topography and climate) and the preservation potential of the lateral-frontal moraine are discussed. The methods used by this research also demonstrate the potential value of SfM photogrammetry and unmanned aerial vehicles for monitoring environmental change and are likely to have wider applications in other geoscientific sub-disciplines.

\section{Introduction}

In Svalbard, the Neoglacial maxima of land-terminating glaciers are typically demarcated by large lateral-frontal moraine complexes (e.g. Bennett et al., 1996; Lyså and Lønne, 2001; Glasser and Hambrey, 2003; Lønne and Lyså, 2005; Lukas et al. 2005; Ewertowski et al. 2012; Midgley et al., 2013). The persistence of relict ice in such moraines is testament to extensive permafrost conditions at the margins of these glaciers (Etzelmüller and Hagen, 2005). However, climatic amelioration and deglaciation are contributing to the de-icing of ice-cored landforms (e.g. 
Etzelmüller, 2000). Whilst the dynamics of de-icing have been studied (e.g. Schomacker 2008; Irvine-Fynn et al., 2011; Bennett and Evans, 2012), the resulting preservation potential of these landforms in the geomorphological record is unclear (Bennett et al., 2000; Evans, 2009). Knowledge regarding the formation and likely stability of glacial landforms, and their preservation is of interest due to the potential for contemporary glacial environments to be used as analogues for formerly glaciated environments in the mid-latitudes (e.g. Hambrey et al., 1997; Graham and Midgley, 2000; Benn and Lukas, 2006; Graham and Hambrey, 2007; Midgley et al., 2007). Moraines are important palaeoenvironmental proxies (Kirkbride and Winkler, 2012), and understanding their genesis and potential for preservation in the geomorphological record is an essential prerequisite for robust interpretations of relict moraine assemblages. Rates of wastage on ice-core moraines are understood to be principally driven by surface processes and topography, rather than climatic conditions (Schomacker, 2008). In the high-Arctic glacial environment, some ice-cored moraines are reported to be unstable and somewhat transient geomorphological features, with ultimately low preservation potential (Bennett et al., 2000; Lukas et al., 2005). Conversely, where debris cover is sufficiently thick, it has been reported that ice-cored moraine may stabilise, undergoing limited or negligible rates of transformation (Ewertowski, 2014; Ewertowski and Tomczyk, 2015). 
Geoscientists now have access to a range of new technologies for monitoring the temporal evolution of geomorphological systems. Specifically, automated photogrammetric techniques such as SfM are an excellent tool for conducting high-resolution topographic surveys (James and Robson, 2012; Westoby et al., 2012; Carrivick et al., 2013; Fonstad et al., 2013). SfM photogrammetry has also been integrated with small format, low-level aerial imagery acquired from small UAVs (e.g. Lucieer et al., 2013; Tonkin et al., 2014; Ryan et al., 2015; Smith and Vericat, 2015; Clapyut et al., 2015; Rippin et al., 2015). Here, SfM photogrammetry is used to document the evolution of an ice-cored lateral-frontal moraine over an 11-year study period, based on images obtained with a UAV in 2014 and archive images from a piloted aircraft in 2003. The principal aims of this study were to: (1) report on the use of SfM for Digital Elevation Model (DEM) production from both archive and small-format low-level aerial imagery for the purpose of assessing environmental change in the high-Arctic; (2) investigate landform evolution at the margins of a high-Arctic glacier; and (3) discuss the geomorphological evolution of ice-cored moraine in relation to landform stability and preservation potential.

\section{Study site}

Austre Lovénbreen is a c. $5 \mathrm{~km}$ long valley glacier located on Brøggerhalvøya, Spitsbergen, Svalbard (78 $53^{\prime} 12^{\prime \prime} \mathrm{N} 12^{\circ} 08^{\prime} 50^{\prime \prime} \mathrm{E} ;$ Fig. 1). 
The glacier's thermal regime was polythermal in 2010 based on our interpretation of GPR (ground-penetrating radar) profiles presented by Saintenoy et al. (2012); the extent of temperate ice appeared to be exceptionally spatially limited, with the glacier being almost entirely coldbased. Austre Lovénbreen has a strong negative mass balance according to Friedt et al. (2012), who reported a mean ablation rate of $0.43 \mathrm{~m} \mathrm{a}^{-1}$ between 1962 and 1995, which increased to $0.70 \mathrm{~m} \mathrm{a}^{-1}$ for the 1995-2009 period.

The glacier is surrounded by mountainous terrain with peaks ranging from $583 \mathrm{~m}$ a.s.I. (Slattofjellet) to $879 \mathrm{~m}$ a.s.I. (Nobilefjellet) at the head of the basin. Surge-type glacier behaviour is widely reported in Svalbard (e.g. Jiskoot et al., 2000). The potential for surge-type behaviour at adjacent glaciers on Brøggerhalvøya has been discussed (e.g. Hansen, 2003; Glasser et al., 2004; Hambrey et al., 2005) and disputed (e.g. Jiskoot et al., 2000; King et al., 2008). However, Midgley et al. (2013) presented evidence that Austre Lovénbreen may have surged close or at its Neoglacial maximum position based upon the interpretation of oblique Norsk Polarinstitutt (NPI) aerial imagery from 1936.

The character of the glacier forefield was documented by Hambrey et al. (1997), with additional field observations reported by Graham (2002). The glacier forefield is characterised by a large arcuate lateral-frontal moraine, which is breached at two locations by the main contemporary glaciofluvial outlets. The lateral-frontal moraine demarcates the Neoglacial 
limit based upon interpretation of ground-level imagery from 1907 (Isachsen, 1912) and oblique Norsk Polarinstitutt (NPI) aerial images from 1936 (Fig. 6 in Midgley et al., 2013). The glacier has receded c. 1 $\mathrm{km}$ from this position. Within the Neoglacial limit, surface hummocks ('hummocky moraine') are identified. Fluted diamicton plains and lineated accumulations of supraglacial debris (e.g. Hambrey et al., 1997) have developed as Austre Lovénbreen receded from its Neoglacial position. More recently, the structural characteristics of the lateral-frontal moraine around the western margin of the forefield were investigated by Midgley et al. (2013) using GPR. This research found that in lateral sections an ice-core constitutes a significant component of the landform, in contrast to the frontal sections where the occurrence of buried ice is limited. This paper maintains the focus on the western margin of the forefield, providing surface morphological data to complement the subsurface data presented by Midgley et al. (2013).

\section{Materials and methods}

\subsection{Data acquisition}

Five images from 2003 were obtained from the UK Natural Environment Research Council (NERC) Airborne Research and Survey Facility (ARSF) for DEM production. These images were collected on August 9th 2003 using a metric camera mounted in a Dornier 228 aircraft, and the contact 
prints scanned to give an approximate ground resolution of $0.2 \mathrm{~m}$ per pixel. In 2014, 10 UAV sorties were flown over a two-day survey period (15th and 16th July 2014). The total area covered by this survey is $c$. $676,000 \mathrm{~m}^{2}$. A DJI S800 multi-rotor UAV equipped with an $18 \mathrm{MP}$ canon EOS-M consumer-grade digital camera was used for image acquisition. The UAV was flown at approximately $100 \mathrm{~m}$ above ground level, giving a ground resolution of $0.02 \mathrm{~m}$ per pixel. A total of 1856 images from this survey were used for DEM production. Further details on this survey setup and validation against a total station derived survey were documented by Tonkin et al. (2014).

Ground control points were surveyed using a Leica 1200 dGPS and postprocessed using RiNEX data obtained from the EUREF Permanent Network station at Ny-Ålesund (http://www.epncb.oma.be/_networkdata/). For the 2003 imagery, three ground control points were used to georeference the point cloud, and to project it to UTM $33 \mathrm{~N}$ coordinate system (Fig. 2). These were the tops of boulders which were visible on the original scanned contact prints, and also readily identified in the field. As the parts of the glacier forefield are likely to be geomorphologically unstable (e.g. Irvine-Fynn et al., 2011), where possible control points were located outside the Neoglacial moraine. The 2014 imagery was georeferenced using 27 ground control-points consisting of A3 sized paper targets placed on snow-free areas of the moraine (Fig. 2). 


\subsection{DEM generation}

DEM generation was conducted in Agisoft Photoscan (v. 1.1.5), a commercial SfM software package. A total of 2035 tie-points were automatically identified on the five images from 2003. For the 2014 imagery, processing was split between two 'chunks' that were merged to form a single DEM of the lateral-frontal moraine. Photoscan identified a total of $5,660,015$ tie points from the 1856 images with the resulting DEM produced from a dense point cloud of $106,484,427$ points. Both SfM DEMs were produced at $0.5 \mathrm{~m}$ per pixel resolution to facilitate comparison between them. On the 2003 DEM, moraine distal slopes were subject to shading, resulting in excessively interpolated elevation data. Zones identified with these issues were removed prior to analysis.

\subsection{Evaluation of DEM quality}

LiDAR data, obtained concurrently with the 2003 aerial imagery were used to independently validate the 2003 DEM. DEM elevations were compared with LiDAR spot heights distributed across the area of interest, giving a vertical RMSE (root mean square error) value of $0.888 \mathrm{~m}$ ( $n=$ $768,296 ; \sigma=0.812 \mathrm{~m})$. The residuals appear to be spatially distributed and increase in areas subject to poor ground control, thus the 2003 SfM DEM may represent an overestimate of the surface topography. However, it is worth noting that the LiDAR data are not error free - the heights have been shown to have an RMSE value of $<0.15 \mathrm{~m}$ in the area of 
interest (Arnold et al., 2006) - but as the two datasets were obtained simultaneously their comparison provides an independent means of estimating DEM error.

Two interrelated issues are likely to account for the vertical RMSE value in this model: (1) the use of relatively low resolution of the imagery on which the DEM is based; and (2) the identification of appropriate 'stable' features to use as ground-control. The first issue reduces the accuracy with which the location of control points can be identified in the imagery. In practice, it is estimated that the identification of control points in the images introduced an error of approximately $1 \mathrm{~m}$. The low resolution also meant that only a small number of large boulders were visible in the imagery, limiting the number of sites available for use as ground control points. This issue was confounded by the need to locate control points on features that were unlikely to have moved during the 11 years between image capture and the field survey. Use of existing 'stable' features for ground control is a limitation of studies that use photogrammetric methods to produce DEMs of changing geomorphological systems (e.g. Schiefer and Gilbert, 2007; Staines et al., 2015), and means it is rarely possible to achieve an optimal distribution of GCPs (ground control points). In this study only three suitable boulders were identified for use as GCPs, which is highly likely to have contributed to an increase in errors (e.g. Clapuyt et al., 2015). 
For the 2014 DEM, errors were calculated for 12 dGPS surveyed check points, which were paper targets visible in the imagery, additional to the 27 control points used to generate the model (Fig. 2). Sub-decimetre vertical errors were obtained for these points $(R M S E=0.048 \mathrm{~m} ; n=12)$. These error estimates give us confidence that the DEM provides an excellent representation of the moraine morphology. For additional validation, randomly generated spot heights $(n=4370)$ from more geomorphologically 'stable' areas (e.g. Staines et al., 2015) outside the Neoglacial limit on the 2003 and 2014 SfM DEMs were compared. Values from these areas show lower error levels $(R M S E=0.374 \mathrm{~m} ; \sigma=0.274$ m), giving confidence in the validity of the two SfM DEMs.

\subsection{DEM differencing and minimum levels of detection}

DEM differencing - subtracting spatially coincident raster grid cells from each other - was used to assess the amount of morphological change between 2003 and 2014. DEM differencing was conducted using the GCD (Geomorphologic Change Detection, ver. 6) plugin of Wheaton et al. (2010) in ArcGIS 10.2.1. The GCD plugin allows for robust error assessment through the use of 'minimum levels of detection' (minLOD). This approach minimises the likelihood of making spurious interpretations of apparent morphological differences that are actually associated with uncertainty in the data. Minimum levels of detection were calculated using a propagated error value derived from error assessments undertaken on 
both topographic surfaces (e.g. Braslington et al., 2003). The technique assumes error within topographic datasets are spatially uniform, and discards changes below this threshold. For the 2003-2014 time period, vertical differences under $0.89 \mathrm{~m}$ were regarded as potentially erroneous, and therefore disregarded for the purposes of assessing morphological change. The majority of this uncertainty results from errors in the 2003 DEM. Three zones $\left(Z_{1}, Z_{2}\right.$ and $\left.Z_{3}\right)$ were clipped from the differenced DEM and used to report on spatial variations in geomorphological change across the landform (Fig. 3A).

\subsection{Feature mapping}

The relative abundance of features indicative of ice-cored moraine degradation were mapped and used to validate the reported rates of surface change derived from the DEM differencing. Features were identified and mapped from ultra-high resolution $(2 \mathrm{~cm}$ per pixel) orthorectified imagery produced from the 2014 survey data. These observations were supplemented by field observations collected simultaneously to the acquisition of the 2014 topographic data. The study area was split into $50 \times 50 \mathrm{~m}$ grid squares $(n=234)$ to allow the relative abundance of geomorphological features indicative of surface change to be qualitatively assessed across the study area. As the precise mode of formation for micro-topographic features indicating landform degradation was unclear, we adopted the non-genetic classification of 'surface linear 
undulations' to refer to features developed by the slumping and/or the extensional surface fracturing of materials in response to surface lowering (e.g. Kjær and Krüger, 2001; Krüger et al., 2010). The location of a large-scale arcuate edge and a linear back-wasting edge were also mapped.

\section{Results}

\subsection{DEM differencing}

A total area of $461,429 \mathrm{~m}^{2}$ was assessed for surface elevation change (Fig. 3A). The lateral-frontal moraine shows a level of geomorphological stability, with change detected on $52 \%\left(238,476 \mathrm{~m}^{2}\right)$ of the study area. Ninety-six percent of the area where change was detected was associated with surface lowering. The total volume difference for the study area was $-377,490 \pm 201,292 \mathrm{~m}^{3}$.

A clear spatial trend characterises the pattern of morphological change. The lateral up-glacier sections are subject to higher rates of surface lowering. Average net surface change in $Z_{1}$ was $-2.56 \mathrm{~m}$ for the study period. Nearly all grid cells in this area were observed outside the minimum level of detection. $Z_{2}$ and $Z_{3}$, which are located in more frontal positions show diminishing rates of detectable change $(92.3 \%$ and $19.9 \%$ of each study area, respectively) and lower rates of average net surface 
change ( -1.49 and $-0.52 \mathrm{~m}$, respectively). Profiles 1,2 and 3 in Fig. 4 also demonstrate reduced surface lowering in frontal positions. On profile 1 , surface lowering is clearly evident on the moraine ridge crest, and less extensively on the ice-proximal and distal slopes. Profiles 2 and 3 show limited geomorphological change with a significant proportion of change falling close to or below the minLOD (Fig. 4). Detectable change on the outwash-plain was limited. Areas of deposition principally occur on moraine distal slopes and in proximity to glaciofluvial drainage systems. Areas that have experienced deposition across the study averaged a depth of $1.42 \pm 0.89 \mathrm{~m}$. However the deposition was extremely spatially and volumetrically limited, only accounting for the movement of 17,952 \pm $11,267 \mathrm{~m}^{3}$ of material ( $4 \%$ of the area of detectable change) opposed to $413,394 \pm 212,243 \mathrm{~m}^{3}$ of change associated with surface lowering across the study area (Fig. 3B). It should be noted that in 2014 c. $11 \%$ of the study area was covered by exceptionally late-lying snow, which was typically located in sheltered areas between pronounced ridges and contributes to the lowering of estimates of surface change over the study period.

\subsection{Geomorphological evidence of surface change}

The occurrence of features indicative of surface evolution were mapped to validate the derived rates of surface change (Fig. 5). Mapped surface features indicative of surface change were identified in lateral-zone of the 
moraine complex; however, the features were less readily identified on the frontal zone of the landform. Out of the 234 survey grid squares assessed, $150(64 \%)$ had no observable evidence of surface evolution. One ice-free actively back-wasting slope was located on the frontal zone of the analysis area adjacent to the western fluvial outlet channel which dissects the Neoglacial lateral-frontal moraine. An additional inactive arcuate back-wasting edge was identified in the lateral zone of the landform (Fig. 5). The spatial occurrence of evidence associated with surface change gives us confidence in the results of the DEM differencing.

\section{Discussion}

\subsection{Comparisons with other glaciers}

A range of studies provide rates of ice-cored landform degradation. Here, rates of landform degradation appear to be limited in comparison to some sites in Svalbard and elsewhere. For example, Irvine-Fynn et al. (2011) report a moraine surface lowering rate of $-0.65 \pm 0.2 \mathrm{~m} \mathrm{a}^{-1}$ at neighbouring Midtre Lovénbreen between 2003 and 2005. Longer-term changes (1984-2004) at Holmstrombreen (Svalbard) were reported to have occurred at a rate of $-0.9 \mathrm{~m} \mathrm{a}^{-1}$ (Schomacker and Kjær, 2008). Rates of surface lowering in temperate Icelandic glacial environments are variable (between -0.015 and $--.4 \mathrm{~m} \mathrm{a}^{-1}$; e.g. Krüger and Kjær, 2000;

Schomacker and Kjær, 2007; Bennett and Evans, 2012). On average, 
surface lowering for the entire study area was considerably lower at -0.16 $\mathrm{m} \mathrm{a}^{-1}$ than reported at some sites in Svalbard. It should be noted that the rate of change may not have remained consistent throughout the study period with moraines known to be subject to short-term changes over consecutive years (e.g. Ewertowski and Tomczyk, 2015). Even in areas with the highest levels of surface lowering (e.g. $z_{1}$ ), only modest rates of average surface change per year were detected $\left(-0.23 \mathrm{~m} \mathrm{a}^{-1}\right)$, which at worst, can be considered an overestimate of surface change, for example, due to errors on the 2003 SfM DEM. These results are similar to the findings of Ewertowski and Tomczyk (2015) who report on surface lowering at the margins of Ebbabreen and Ragnarbreen in Petuniabukta. Here, whilst areas of back-wasting ice were quantified to undergo changes of up to $1.8 \mathrm{~m} \mathrm{a}^{-1}$, lower levels of transformation (e.g. below 0.3 $\mathrm{m} \mathrm{a}^{-1}$ ), were quantified, highlighting the relative stability of some icecored moraine in Svalbard. Similarly, at Austre Lovénbreen, a significant proportion of the study area (52\%) was below the minimum level of detection implying no or exceptionally limited geomorphological change between 2003 and 2014.

\subsection{Moraine preservation potential}

Moraines in the high-Artic glacial environment are understood to be highly vulnerable to thermo-erosion and mass movement facilitated by fluvial undercutting. This can result in high rates of landform transformation 
(Ewertowski and Tomczyk, 2015). The evidence presented here indicates that such surface processes are less important with regard to the transformation of the lateral frontal moraine at Austre Lovénbreen. A surface excavation in proximity to $Z_{1}$ showed that the debris mantle was surprisingly thick at $1.6 \mathrm{~m}$. At this site, and potentially others, whilst rates of moraine surface lowering may be rather high, a relatively thick and evenly distributed debris-layers can permit the relative stabilisation of icecored moraine where the coupling of slope and fluvial processes (e.g. Etzelmüller et al., 2000) exert less influence on moraine transformation. This is largely due to the less topographically confined setting of the lateral-frontal complex at Austre Lovénbreen, which results in the glaciofluvial system being well separated from the moraine. The result is a low level of transformational activity, which principally occurs via downwasting (e.g. Fig. 5). An implication of this study is that the ice-cored moraines formed at Austre Lovénbreen, and potentially other valley glaciers in Svalbard (e.g. the recent results of Ewertowski and Tomczyk, 2015), may have higher preservation potential than previously recognised as insulating debris is not reworked and remains in situ.

During the final stage of moraine development, two end-points are envisaged: (1) a fully stabilised ice-cored moraine, which is in equilibrium with its environment; or (2) an ice-free lateral-frontal moraine complex (Fig. 6). The first scenario requires a thick debris mantle to develop that exceeds the permafrost active layer allowing buried-ice to be a persistent landscape feature. It is unclear whether the first scenario is plausible. Ice- 
cored 'controlled' moraines are understood to be poorly preserved in the geomorphological record (Evans, 2009). Buried-ice up to 200 years of age has been documented in moraines at the margins of temperate Icelandic glaciers (e.g. Everest and Bradwell, 2003). Examples of where the preservation of buried-ice has been permitted on longer timescales include formerly glaciated continental settings (e.g. Ingólfsson and Lokrantz, 2003; Murton et al., 2005), and cold deserts where buried-ice is suggested to have existed for several millennia under permafrost conditions (Sugden et al., 1995; Schäfer et al. 2000). Waller et al. (2012) highlighted that the preservation of buried-ice may be permitted on geological timescales if it is located at depths unaffected by seasonal thaw. However, the high-Arctic glacial environment in Svalbard is known for its highly unstable ice-cored moraine, and rapidly progressing mass wasting processes (Bennett et al., 2000; Schomacker, 2008; Irvine-Fynn et al., 2011; Ewertowski and Tomczyk, 2015). Schomacker (2008) showed that climatic variables are only weakly correlated with rates of ice-cored backwastage occurring at 14 different glaciers; the implication being that surface processes and topography are more important determinates of moraine disintegration. However, this result may not hold at Austre Lovénbreen, where very limited evidence of back-wasting was observed in the field by the authors in 1999, 2009 and 2014 (e.g. Fig. 5).

Alternatively, the second end-point requires complete de-icing of the moraine, where the active layer may continue to exceed the depth of the debris mantle for the duration of the secondary deglaciation process 
resulting in continued and complete melting of buried-ice despite an increasing debris thickness. The findings of Midgley et al. (2013) indicated that sediment concentration within the moraine is low in lateral positions compared to frontal positions. As a result, following complete de-icing the lateral features which have a significant ice component are likely to be topographically low and diffuse relative to the frontal features where the total volume of sediment appears to be much larger. This is an important consideration where high-Arctic polythermal glaciers are used as an analogue for relict glacial landsystems in the geomorphological record.

\subsection{Controls on rates of down-wasting}

The physical properties of the insulating debris layer such as its thickness, water content and thermal conductivity influence rates of moraine downwastage (Schomacker, 2008). The importance of rainwater depends on the extent to which the influence of heat advection via percolation is countered by evaporation from the ground surface (Sakai et al., 2004). Rainwater has been shown to be important in facilitating top-melt in highly permeable substrates (Reznichenko et al., 2010), at least where cool and damp atmospheric conditions limit evaporation. Conversely, block-rich material with high surface roughness has low thermal conductivity and can obstruct the development of winter snow-cover depressing the lower limit of permafrost in mountain terrain (Etzelmüller and Frauenfelder, 2009). At Austre Lovénbreen, the substrate typically 
consists of clast-rich diamictons which are overlain by gravels with a variable fine component in many places. Diamictons have been associated with variable porosity values (e.g. Parriaux and Nicoud, 1990; Kilfeather and van der Meer, 2008; Burki et al., 2010; Worni et al., 2012). Diamicton with silt and clay components and frozen horizons will lower the permeability of the debris, and serve to impede heat advection by water during summer months, thus limiting ice-ablation (e.g. Reznichenko et al., 2010).

Local topographic controls also influence air-temperature and subsequently permafrost distribution (Harris et al. 2009). Strong topographic shading has been reported as an influence on de-icing at other sites in Svalbard (e.g. Lyså and Lønne , 2001). Given the proximity of the landform to Slattofljettet (582 m), rates of moraine down-wastage in up-glacier sections of the landform may be influenced. Modelling of these shading effects is likely to be an interesting avenue of research in relation to moraine disintegration and more generally, permafrost distribution and properties in mountainous terrain.

A further confounding factor is snow-cover which is known to limit the influence of atmospheric heat on ground temperature (Stieglitz et al., 2003). Whilst in winter snow may permit higher ground temperature in relation to mean air temperatures (Stieglitz et al., 2003), late lying snow is likely to play an additional role limiting the susceptibility of buried-ice to surface warming. Further work investigating the influence of snow cover 
and snow-depth in relation to moraine down-wastage could elucidate how significant a role it plays in reducing down-wastage.

\subsection{Spatial variations within the moraine system}

Diminishing rates of landform change from areas $Z_{1}$ to $Z_{3}$ (Fig. 3) correspond with an increase in the proportion of debris relative to ice from lateral to frontal positions (e.g. Midgley et al., 2013). Spatially variable amounts of buried-ice imply that the mode of moraine formation is not consistent across the moraine complex (e.g. Hambrey and Glasser, 2012). Lateral sections conform to the 'controlled' ice-cored model of moraine formation (e.g. Evans, 2009) where the release of material from debrisrich folia result in surface linearity and form an insulating surface layer for underlying glacier-ice. The reduced rates of observed surface lowering in the frontal sections, and the presence of surface hummocks indicate that separate glaciological and geomorphological processes are responsible for the emplacement of moraine at different locations along the lateral-frontal complex. Here, structural glaciology and the preferential entrainment of basal debris in frontal locations is likely to be important. For example, studies have investigated the development of surface hummocks ('hummocky moraine') in relation to the stacking of englacial material along thrusts planes (e.g. Hambrey et al., 1996; 1997; Bennett et al., 1998; Graham, 2002; Midgley et al., 2007). The processes described in these papers may, in part, be responsible for areas of surface hummocks 
on the moraine complex and lower levels of ice incorporation. It is worth noting that additional moraine forming processes such as pushing and permafrost deformation are documented to occur in ice-marginal environments in Svalbard (Etzelmüller et al., 1996; Boulton et al., 1999).

\section{Summary}

The evolution of an ice cored lateral-frontal moraine over an 11-year period was assessed at the high-Arctic polythermal glacier Austre Lovénbreen, Svalbard. Repeat DEMs and DEMs of difference were generated from archive and UAV-derived aerial imagery using SfM and minLOD methods. Average depth of surface lowering for the entire study area was estimated to be $-1.75 \pm 0.89 \mathrm{~m}$. Landform evolution occurred most rapidly on lateral sections of the landform. In contrast to many other sites in Svalbard, field evidence highlights that the moraine appears to be de-icing predominately by down-wastage, affording the landform higher levels of stability. Atypical of de-icing moraines in the high-Arctic, slope and fluvial driven change appear to be less significant. There may be potential for the buried-ice to be stabilised and preserved as a palaeoglaciological archive of former Neoglacial ice dynamics. The highresolution UAV-derived dataset serves as a benchmark for future studies of monitoring geomorphological change on the lateral-frontal moraine at Austre Lovénbreen, achieving a vertical RMSE value of $0.048 \mathrm{~m}$ for independent check points. This study adds to the growing body of 
evidence that a combination of UAV-derived imagery, a consumer-grade digital camera and SfM methods are highly appropriate for monitoring of geomorphological change. The errors associated with DEM generation from archived conventional aerial imagery were substantially larger, partly as a result of the lower image resolution, and partly the limited availability of appropriate features to use for ground control. Such issues are common to the extraction of topographic data from archive imagery in changing environments, and may limit the application of this approach. Nevertheless, the derived DEM was of sufficient quality to be useful for estimating the rate of de-icing over the 11 -year period investigated. It is concluded that the use of SfM photogrammetry for extracting morphological data from a range of aerial imagery is appropriate for monitoring environmental change and is likely to have wider applications in other geoscientific sub-disciplines.

\section{Acknowledgments}

This research was undertaken whilst TNT was funded by a Nottingham Trent University VC bursary. Additional grants from Nottingham Trent University to NGM and from the Manchester Geographical Society to SJC made this work possible. The fieldwork benefited from the logistical support provided by Nick Cox of the UK Natural Environment Research Council (NERC) Arctic Research Station. Anya Wicikowski is thanked for assisting with field data collection. Aerial image data from the UK Natural 
Environment Research Council (NERC) Airborne Research and Survey Facility (ARSF) are provided courtesy of NERC via the NERC Earth Observation Data Centre (NEODC). Permission to conduct aerial survey work was obtained from the Norwegian CAA and the relevant local authorities. Dr. David Rippin is thanked for providing advice on Norwegian airspace permission applications. Additional thanks go to Marc Shallbrook for providing advice on data preparation. The manuscript was improved following helpful comments from Dr. Marek Ewertowski and one anonymous reviewer. 
Fig. 1. Location map of Svalbard and the study site in relation to Austre Lovénbreen (AL). Data from Norwegian Polar Institute (2014).

Fig. 2. Locations of ground-control applied to the 2003 and 2014 topographic datasets and the independent check-points used for error analysis on the 2014 DEM. The black line indicates the extent of the 2003 SfM DEM. The orthophoto is produced from Aerial image data in 2003, from the UK Natural Environment Research Council (NERC) Airborne Research and Survey Facility (ARSF). These data are provided courtesy of NERC via the NERC Earth Observation Data Centre (NEODC).

Fig. 3. Surface change over the western lateral-frontal moraine of Austre Lovénbreen. (A) DEM of difference for 2003-2014. The black lines are contour data (m.a.s.I.) derived from the 2014 DEM. The locations of three zones of analysis $\left(Z_{1}, Z_{2}\right.$ and $\left.Z_{3}\right)$ are shown. (B) Surface change in relation to area and volume. (C) Average net surface change for $Z_{1}, Z_{2}$ and $Z_{3}$ with the minimum level of detection (minLOD) highlighted by the dotted line.

Fig. 4. Surface evolution over the 11-year study period demonstrated by three topographic profiles. (A) The locations of the three profiles. (B) Surface change along profiles 1-3 between 2003 and 2014.

Fig. 5. Relative abundance of geomorphological features indicative of surface change across the study area.

Fig. 6. Conceptual model for the evolution of the lateral-frontal moraine under the scenarios of partial and complete de-icing. 


\section{References}

Arnold N.S., Rees. W.G., Devereux, B.J. and Amable., G.S. 2006. Evaluating the potential of high-resolution airborne LiDAR data in glaciology. International Journal of Remote Sensing, 27 (6), 1233-1251. doi: $10.1080 / 01431160500353817$

Benn, D.I., Lukas, S., 2006. Younger Dryas glacial landsystems in North West Scotland: An assessment of modern analogues and palaeoclimatic implications. Quaternary Science Reviews. 25, 2390-2408. doi:10.1016/j.quascirev.2006.02.015

Bennett, G.L. \& Evans, D.J.A. 2012. Glacier retreat and landform production on an overdeepened glacier foreland: the debris-charged glacial landsystem at Kviárjökull, Iceland. Earth Surface Processes and Landforms, 37 (15), 1584-1602. doi: 10.1002/esp.3259

Bennett, M.R., Huddart, D., Hambrey, M.J. and Ghienne, J.F. 1996. Moraine Development at the High-Arctic Valley Glacier Pedersenbreen, Svalbard. Geografiska Annaler. Series A, Physical Geography, 78 (4), 209-222.

Bennett, M.R., Hambrey, M.J., Huddart, D. and Glasser, N.F., 1998. Glacial thrusting and moraine-mound formation in Svalbard and Britain: the example of Coire a' Cheud-chnoic (Valley of hundred hills), Torridon, Scotland. Quaternary Proceedings, 6, 17-34. 
Bennett, M.R., Huddart, D., Glasser, N.F. and Hambrey, M.J. 2000. Resedimentation of debris on an ice-cored lateral moraine in the highArctic (Kongsvegen, Svalbard). Geomorphology, 35, 21-40. doi:10.1016/S0169-555X(00)00017-9

Boulton, G., van der Meer, J.J.M., Beets, D.J., Hart, J.K. and Ruegg, G.H.J. 1999. The sedimentary and structural evolution of a recent push moraine complex: Holmstrombreen, Spitsbergen. Quaternary Science Reviews, 18, $339-371$.

doi: $10.1016 / S 0277-3791(98) 00068-7$

Brasington, J., Langham, J. and Rumsby B. 2003. Methodological sensitivity of morphometric estimates of coarse fluvial sediment transport. Geomorphology, 53 (3-4), 299-316. doi: 10.1016/S0169$555 \times(02) 00320-3$

Burki, V., Hansen, L., Fredin, O., Andersen, T.A., Beylich, A.A., Jaboyedoff, M., Larsen, E., Tønnesen, J.-F. 2010. Little Ice Age advance and retreat sediment budgets for an outlet glacier in western Norway. Boreas, 39 (3) (2010), 551-566. doi: 10.1111/j.1502-3885.2009.00133.x

Clapuyt, F., Vanacker, V., Van Oost, K. 2015. Reproducibility of uavbased earth topography reconstructions based on structure-from-motion algorithms. Geomorphology, In press. doi:10.1016/j.geomorph.2015.05.011 
Carrivick, J.L., Smith, M.W., Quincey, D.J. and Carver, S.J. 2013. Developments in budget remote sensing for the geosciences. Geology Today, 29, 138-143. doi: 10.1111/gto.12015

Etzelmüller, B. 2000. Quantification of thermo-erosion in pro-glacial areas - examples from Svalbard. Zeitschrift für Geomorphologie, 44, 343-361.

Etzelmüller, B. and Frauenfelder, R. 2009. Factors Controlling The Distribution of Mountain Permafrost in The Northern Hemisphere and Their Influence on Sediment Transfer. Arctic, Antarctic, and Alpine Research, 41 (1), 48-58. DOI: 10.1657/1938-4246(08026)[ETZELMUELLER]2.0.CO;2

Etzelmüller, B. and Hagen, J.O. 2005. Glacier permafrost interaction in arctic and alpine environments - examples from southern Norway and Svalbard. In: Harris, C. \& Murton, J. (eds.). Cryospheric systems Glaciers and Permafrost. British Geol. Soc., Spec. Publ. 242, 11-27.

Etzelmüller, B., Hagen, J.O., Vatne, G., Ødegård, R.S., Sollid, J.L. 1996. Glacier debris accumulation and sediment deformation influenced by permafrost, examples from Svalbard. Ann. Glaciol., 22, 53 - 62.

Etzelmüller, B., Ødegård, R.S., Vatne, G., Mysterud, S., Tonning, T and Sollid, J.L. 2000. Glacier characteristics and sediment transfer system of Longyearbreen and Larsbreen, western Spitsbergen. Norsk Geografisk Tidsskrift, 54 (4), 157-168. DOI:10.1080/002919500448530 
Evans, D.J.A. 2009. Controlled moraines: origins, characteristics and palaeoglaciological implications. Quaternary Science Reviews, 28 (3-4), 181-260. doi: 10.1016/j.quascirev.2008.10.024

Everest, J. and Bradwell, T. 2003. Buried glacier ice in southern Iceland and its wider significance. Geomorphology, 52 (3-4). 347-358. http://dx.doi.org/10.1016/S0169-555X(02)00277-5

Ewertowski M., Kasprzak L., Szuman I., Tomczyk A.M., 2012. Controlled, ice-cored moraines: sediments and geomorphology. An example from Ragnarbreen, Svalbard. Zeitschrift für Geomorphologie, 56 (1), 53-74. doi: $10.1127 / 0372-8854 / 2011 / 0049$

Ewertowski. M. 2014. Recent transformations in the high-Arctic glacier landsystem, Ragnarbreen, Svalbard. Geografiska Annaler: Series A (Physical Geography), 96, 265-285. doi: 10.1111/geoa.12049

Ewertowski, M. and Tomczyk, A.M. 2015. Quantification of the ice-cored moraines' short-term dynamics in the high-Arctic glaciers Ebbabreen and Ragnarbreen, Petuniabukta, Svalbard. Geomorphology, 234, 211-227. doi: 10.1016/j.geomorph.2015.01.023

Friedt, J.-M., Tolle, F., Bernard, É., Griselin, M., Laffy, D and Marlin, C. 2012. Assessing the relevance of digital elevation models to evaluate glacier mass balance: application to Austre Lovénbreen (Spitsbergen, $79^{\circ}$ N). Polar Record, 48 (244) 2-10. DOI: $10.1017 /$ S0032247411000465 
Fonstad, M.A., Dietrich, J.T., Courville, B.C. and Carbonneau, P.E. 2013. Topographic structure from motion: a new development in photogrammetric measurements. Earth Surface Processes and Landforms, 20, 817-827. doi: 10.1002/esp.3366

Graham, D.J. 2002. Moraine-mound formation during the Younger Dryas in Britain and the Neoglacial in Svalbard. PhD thesis University of Wales, Aberystwyth.

Graham, D.J. and Hambrey, M.J. 2007. Sediments and landforms in an upland glaciated-valley landsystem: Upper Ennerdale, English Lake District in M.J. Hambrey, P. Christoffersen, N.F. Glasser NF and B. Hubbard (Eds), Glacial Sedimentary Processes and Products, Blackwell, Oxford (2007), 235-256.

Graham, D.J. and Midgley, N.G. 2000. Moraine-mound formation by englacial thrusting: the Younger Dryas moraines of Cwm Idwal, North Wales. In: A.J. Maltman, B. Hubbard and M.J. Hambrey (eds.), Deformation of Glacial Materials. London: Geological Society, pp. 321-336. http://dx.doi.org/10.1144/GSL.SP.2000.176.01.24

Glasser, N.F. and Hambrey, M.J. 2003. Ice-marginal terrestrial landsystems: Svalbard polythermal glaciers in D.J.A. Evans (Ed.), Glacial Landsystems, Hodder Arnold, London (2003), 65-88.

Glasser, N.F., Coulsen, S.J., Hodkinson, I.D. and Webb, N.R. 2004. Photographic evidence of the return period of a Svalbard surge-type 
glacier: a tributary of Pedersenbreen, Kongsfjord. Journal of Glaciology, 50 (169), 307-308.

Hambrey, M.J., Dowdeswell, J.A., Murray, T., Porter, P.R., 1996. Thrusting and debris entrainment in a surging glacier: Bakaninbreen, Svalbard. Annals of Glaciology, 22, 241-248.

Hambrey, M.J., Huddart, D., Bennett, M.R. and Glasser, N.F. 1997. Genesis of "hummocky moraines" by thrusting in glacier ice: evidence from Svalbard and Britain. Journal of the Geological Society, London. 154, 623-632. doi: $10.1144 /$ gsjgs.154.4.0623

Hambrey, M.J., Murrary, T., Glasser, N.F., Hubbard, A., Hubbard, B., Stuart, G., Hansen, S. and Kohler, J. 2005. Structure and changing dynamics of a polythermal valley glacier on a centennial time-scale: midre Lovénbreen, Svalbard. Journal of Geophysical Research, Earth Surface, p. F010006.

Hambrey, M.J. and Glasser, N.F. 2012. Discriminating glacier thermal and dynamic regimes in the sedimentary record, Sedimentary Geology, 251252, 1-33. doi:10.1016/j.sedgeo.2012.01.008

Hansen, S. 2003. From surge-type to non-surge type glacier behaviour: Midre Lovénbreen, Svalbard. Annals of Glaciology, 36, 97-102.

Harris, C., Arenson, L.U., Christiansen, H.H., Etzelmüller, B., Fraunfelder, R., Gruber., Haeberli, W., Hauck, C., Hölzle, M., Humlum, O., Isaksen, K. Kääb, A., Kern-Lütschg, M.A., Lehning, M., Matsuoka, N., Murton, J.B., 
Nötzlie, J., Philips, M., Ross, N., Seppäläl, M., Springman, S.M. and Mühll, D.V. 2009. Permafrost and climate in Europe: Monitoring and modelling thermal, geomorphological and geotechnical responses. 92 (3-4), 117171. doi: 10.1016/j.earscirev.2008.12.002

Isachsen, G. 1912. Exploration du Nord-Ouest du Spitsberg entreprise sous les auspices de S.A.S. le Prince de Monaco par la Mission Isachsen. Fascicule XL. Imprimerie de Monaco.

Irvine-Fynn, T.D.L., Barrand, N.E., Porter, P.R., Hodson, A.J. and Murray, T. 2011. Recent High-Arctic glacial sediment redistribution: a process perspective using airborne lidar. Geomorphology, 125 (1), 27-39. doi:10.1016/j.geomorph.2010.08.012

Ingólfsson, Ó and Lokrantz, H. 2003. Massive ground ice body of glacial origin at Yugorski Peninsula, arctic Russia. Permafrost and Periglacial Processes, 14 (3), 199-215. doi: 10.1002/ppp.455

James, M. R. and Robson, S. 2012. Straightforward reconstruction of 3D surfaces and topography with a camera: Accuracy and geoscience application, J. Geophys. Res., 117, F03017, doi: 10.1029/2011JF002289

Jiskoot, H., Murray, T. and Boyle, P.J. 2000. Controls on the distribution of surge-type glaciers in Svalbard. Journal of Glaciology, 46 (154) 412422. doi: $10.3189 / 172756500781833115$

King, E.C., Smith, A.M., Murray, T. and Stuart, G.W. 2008. Glacier-bed characteristics of midtre Lovénbreen, Svalbard, from high - resolution 
seismic and radar surveying, J. Glaciol., 54, 145 - 156, doi: $10.3189 / 002214308784409099$.

Kilfeather , A.A. and van der Meer, J.J.M. 2008. Pore size, shape and connectivity in tills and their relationship to deformation processes. Quaternary Science Reviews, 27 (3-4) 250-266. doi: 10.1016/j.quascirev.2006.12.015

Kirkbride, M.P. and Winkler, S. 2012. Correlation of Late Quaternary moraines: impact of climate variability, glacier response, and chronological resolution. Quaternary Science Reviews, 46, 1-29. doi:10.1016/j.quascirev.2012.04.002

Kjær, K.H and Krüger, J. 2001. The final phase of dead-ice moraine development: processes and sediment architecture, Kötlujökull, Iceland. Sedimentology, $48 \quad(5), \quad 935-952 . \quad$ doi: 10.1046/j.13653091.2001.00402.x

Krüger, J. and Kjær, K.H. 2000. De-icing progression of ice-cored moraines in a humid, sub-polar climate, Kotlujökull, Iceland. The Holocene, 48, 935-952. doi: 10.1191/09596830094980

Krüger, J., Kjær, K.H., Schomacker, A. 2010. Dead-Ice Environments: A Landsystems Model for a Debris-Charged, Stagnant Lowland Glacier Margin, Kötlujökull. Developments in Quaternary Sciences. 13, 105-126. doi:10.1016/S1571-0866(09)01307-4 
Lønne, I. and Lyså, A. 2005. Deglaciation dynamics following the Little Ice Age on Svalbard: Implications for shaping of landscapes at high latitudes. Geomorphology 72, 300-319. doi:10.1016/j.geomorph.2005.06.003

Lucieer, A., de Jong, S.M, and Turner, D. 2013. Mapping landslide displacements using Structure from Motion (SfM) and image correlation of multi-temporal UAV photography. Progress in Physical Geography, 38 (1), 97-116. doi: 10.1177/0309133313515293

Lukas, S., Nicholson, L.I., Ross, F.H and Humlum, O. 2005 Formation, meltout processes and landscape alteration of High-Arctic ice-cored moraines-examples from Nordenskiold Land, Central Spitsbergen. Polar Geography, 29 (3), 157-187. doi: 10.1080/789610198

Lyså, A. and Lønne. I. 2001. Moraine development at a small High-Arctic valley glacier: Rieperbreen, Svalbard. Journal of Quaternary Science, 16 (6), 519-529. doi: 10.1002/jqs.613

Midgley, N.G., Glasser, N.F. and Hambrey, M.J. 2007. Sedimentology, structural characteristics and morphology of a Neoglacial high-Arctic moraine-mound complex: Midre Lovénbreen, Svalbard. in: M.J. Hambrey, P. Christoffersen, N.F. Glasser, B. Hubbard (Eds.), Glacial Sedimentary Processes and Products, International Associated of Sedimentologists, Special Publication, 39 (2007), 11-23.

Midgley, N.G., Cook, S.J., Graham, D.J. and Tonkin, T.N. 2013. Origin, evolution and dynamic context of a Neoglacial lateral-frontal moraine at 
Austre Lovénbreen, Svalbard. Geomorphology, 198, 96-106. doi:10.1016/j.geomorph.2013.05.017

Murton J.B., Whiteman, C.A., Waller, R.I., Pollard, W.H., Clark, I.D. and Dallimore, S.R. 2005. Basal ice facies and supraglacial melt-out till of the Laurentide Ice Sheet, Tuktoyaktuk Coastlands, western Arctic Canada. Quaternary Science Reviews. 24 (5-6), 681-708. doi:10.1016/j.quascirev.2004.06.008

Norwegian Polar Institute 2014. Kartdata Svalbard 1:100 000 (S100 Kartdata). Troms $\varnothing$, Norway: Norwegian Polar Institute. Available at: https://data.npolar.no/dataset/645336c7-adfe-4d5a-978d-9426fe788ee3

Parriaux, A. and Nicoud. G.F. 1990. Hydrological behaviour of glacial deposits in mountainous areas, in: L. Molnár (Ed.), Hydrology of Mountainous Areas, International Association of Hydrological Sciences, Publication, 190 (1990), 291-311.

Reznichenko, N., Davies, T., Shulmeister, J. and McSaveney, M. 2010. Effects of debris on ice surface melting rates: an experimental study. Journal of Glaciology, 56 (197), 384-394. doi: $10.3189 / 002214310792447725$

Rippin, D.M., Pomfret, A. and King, N. 2015. High resolution mapping of supra-glacial drainage pathways reveals link between micro-channel drainage density, surface roughness and surface reflectance. Earth Surface Processes and Landforms. Early view. doi: 10.1002/esp.3719 
Ryan, J.C., Hubbard, A.L., Box, J.E., Todd, J., Christoffersen, P., Carr, J.R., Holt, T.O., Snooke, N. 2015. UAV photogrammetry and structure from motion to assess calving dynamics at Store Glacier, a large outlet draining the Greenland ice sheet. The Cryosphere, 9, 1-11. doi:10.5194/tc-9-12015

Sakai, A., Fujita, K. and Kubota. J. 2004. Evaporation and percolation effect on melting at debris-covered Lirung Glacier, Nepal Himalayas, 1996. Bulletin of Glaciological Research, 21, 9-16.

Saintenoy, A., Friedt, J.-M., Booth, A.D., Tolle, F., Bernard, E., Laffly, D., Marlin, C. and Griselin, M. 2012. Deriving ice thickness, glacier volume and bedrock morphology of Austre Lovénbreen (Svalbard) using GPR. Near Surface Geophysics, 11 (2), 253-26. doi: 10.3997/18730604.2012040

Schäfer, J.M., Heinrich, B., Denton, G.H., Ivy-Ochs, S., Marchant, D.R., Schlüchter, C. and Rainer, W. 2000. The oldest ice on Earth in Beacon Valley, Antarctica: new evidence from surface exposure dating. Earth and Planetary Science Letters. 179 (1), 91-99.

Schiefer, E. and Gilbert, R. 2007. Reconstructing morphometric change in a proglacial landscape using historical aerial photography and automated DEM generation. Geomorphology, $88 \quad(1-2), \quad$ 167-178. doi:10.1016/j.geomorph.2006.11.003 
Schomacker, A. 2008. What controls dead-ice melting under different climate conditions? A discussion. Earth-Science Reviews, 90 (3-4), 103113.

Schomacker, A. and Kjær, K.H. 2007. Origin and de-icing of multiple generations of ice-cored moraines at Brúarjökull, Iceland. 36 (4), 411425.

Schomacker, A. and Kjær, K.H. 2008. Quantification of dead-ice melting in ice-cored moraines at the high-Arctic glacier Holmstrombreen, Svalbard. Boreas, 37, 211-225. doi: 10.1111/j.1502-3885.2007.00014.x.

Smith, M.W. and Vericat, D. 2015. From experimental plots to experimental landscapes: topography, erosion and deposition in subhumid badlands from Structure-from-Motion photogrammetry. Earth Surface Processes and Landforms. Early View. doi: 10.1002/esp.3747

Staines, K.E., Carrivick, J.L., Tweed, F.S., Evans, A.J., Russell, A.J., Jóhannesson, T. and Roberts, M. 2015. A multi-dimensional analysis of proglacial landscape change at Sólheimajökull, southern Iceland. Earth Surface Processes and Landforms. Available online from 14/11/2014. doi: 10.1002/esp.3662

Stieglitz, M., Déry, S.J., Romanovsky, V.E., Osterkamp, T.E. 2003. The role of snow cover in the warming of arctic permafrost. Geophysical Reserch Letters, 30 (13), 1721. doi:10.1029/2003GL017337 
Sugden, D.E., Marchant, D.R., Potter Jr. N., Souchez, R.A., Denton, G.H., Swischer III, C.C. and Tison, J.-L. 1995. Preservation of Miocene glacier ice in East Antarctica. Nature, 376, 412-414. doi:10.1038/376412a0

Tonkin, T.N., Midgley, N.G., Graham, D.J. and Labadz, J.C. 2014. The potential of small unmanned aircraft systems and structure-from-motion for topographic surveys: A test of emerging integrated approaches at Cwm Idwal, North Wales. Geomorphology, 226, 35-43. doi: 10.1016/j.geomorph.2014.07.021

Waller, R.I., Murton, J.B. and Kristensen, L. 2012. Glacier-permafrost interactions: Processes, products and glaciological implications. Sedimentary Geology, 255, 1-28. doi: /10.1016/j.sedgeo.2012.02.005

Wheaton, J.M., Brasington, J., Darby, S.E. and Sear, D.A. 2010. Accounting for uncertainty in DEMs from repeat topographic surveys: improved sediment budgets. Earth Surface Processes and Landforms, 35 (2), 136-156. doi: 10.1002/esp.1886

Worni, R., Stoffel, M., Huggel, C., Volz, C., Casteller, A. and Luckman, B. 2012. Analysis and dynamic modeling of a moraine failure and glacier lake outburst flood at Ventisquero Negro, Patagonian Andes (Argentina). Journal of Hydrology, 444-445, 134-145. doi: $10.1016 / j . j h y d r o l .2012 .04 .013$

Westoby, M., Brasington J, Glasser, N.F., Hambrey, M.J. and Reyonds, M.J. 2012. Structure-from-Motion photogrammetry: a low-cost, effective tool 
for geoscience applications. Geomorphology, 179, 300-314. doi:10.1016/j.geomorph.2012.08.021 


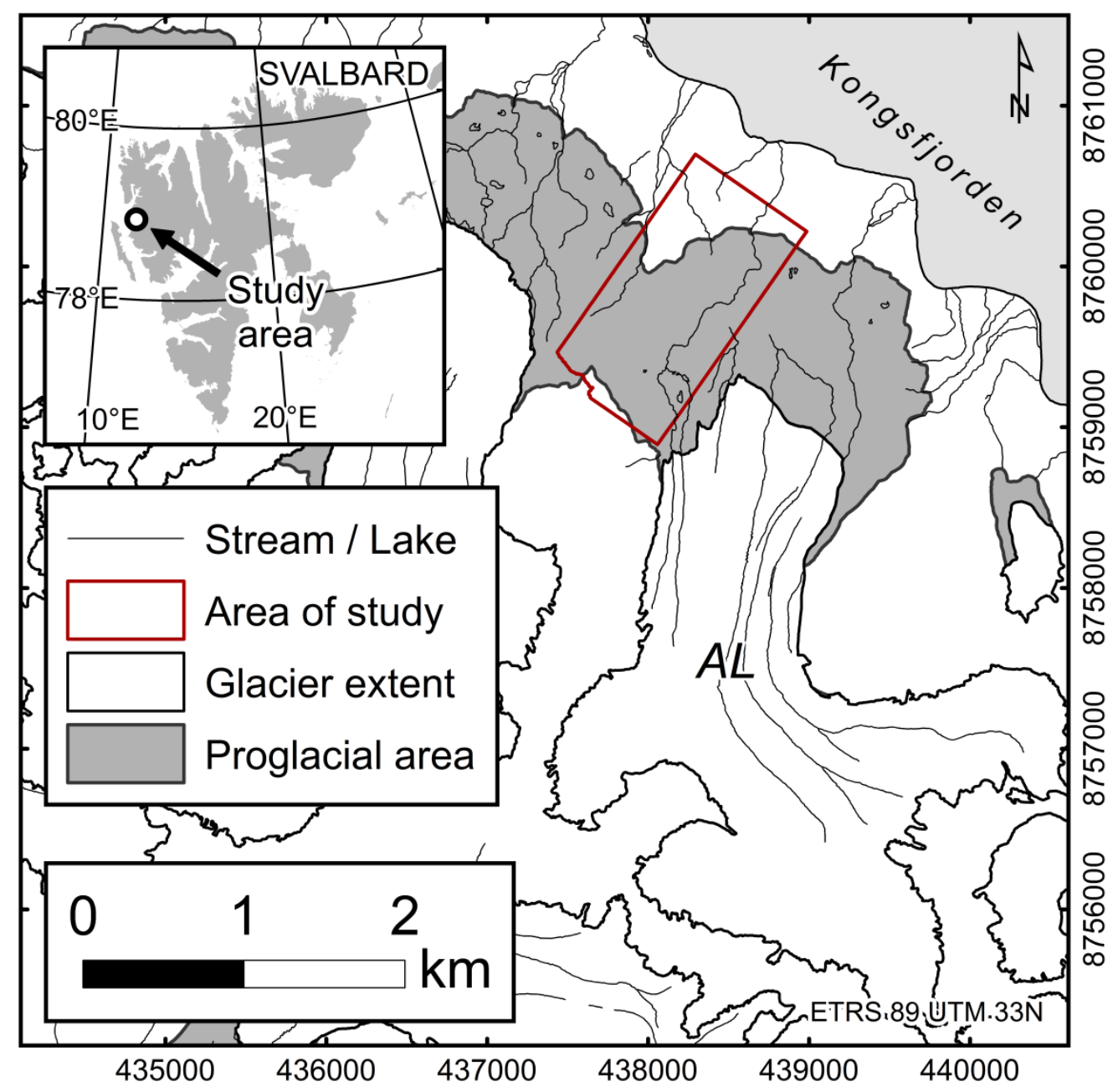

Figure 1 


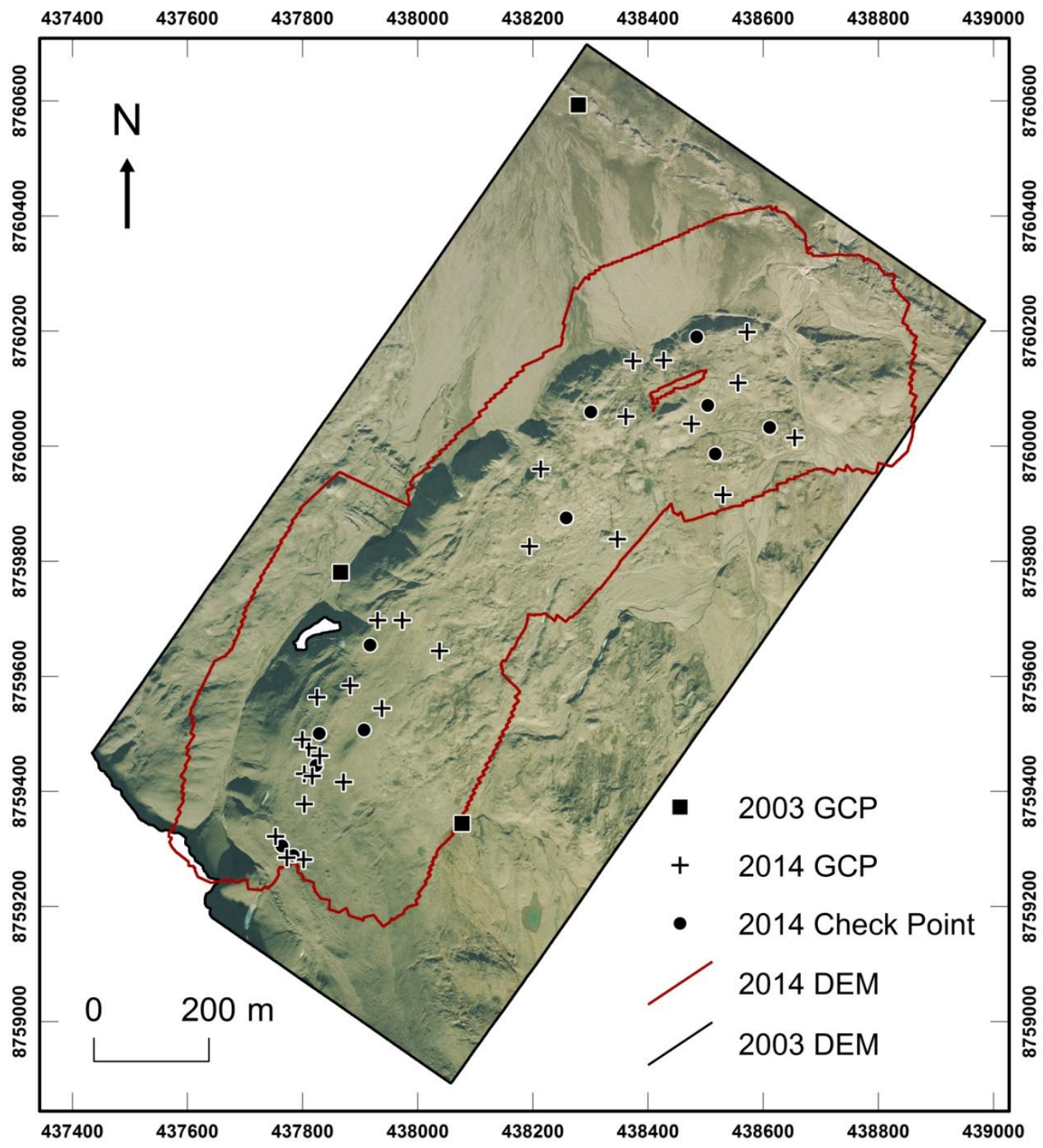

Figure 2 
A N

$\uparrow$

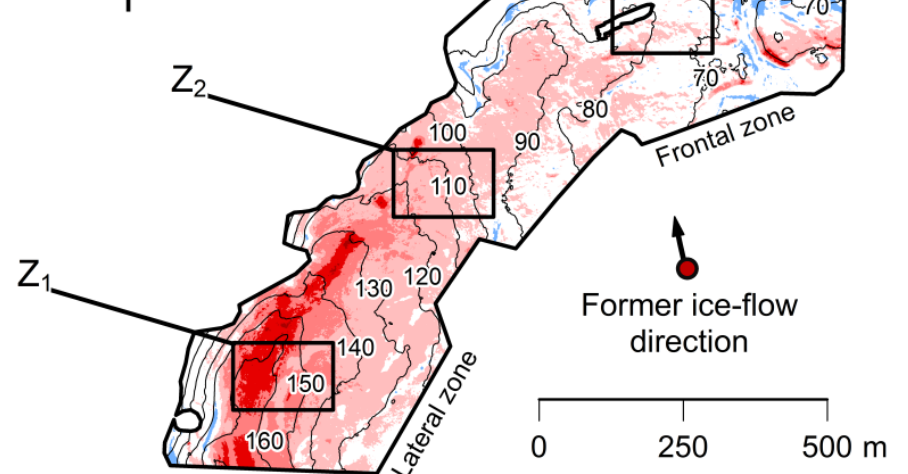

Surface

Change (m)

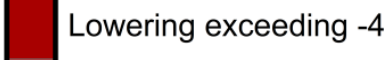

-4 to -3

-3 to -2

-2 to $\min L O D$

No change Increase
B

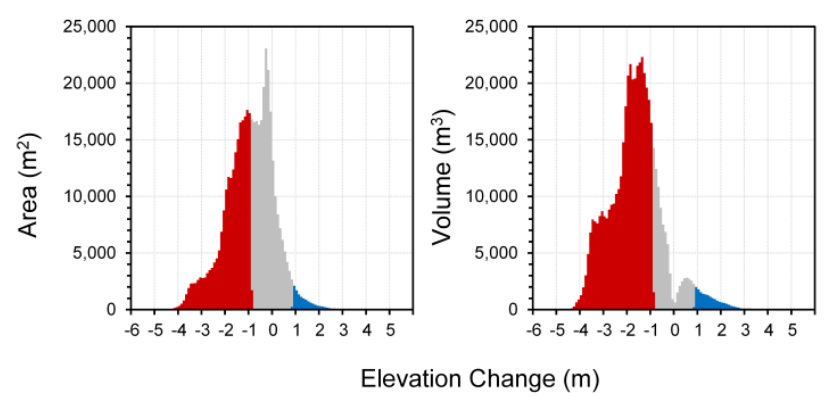

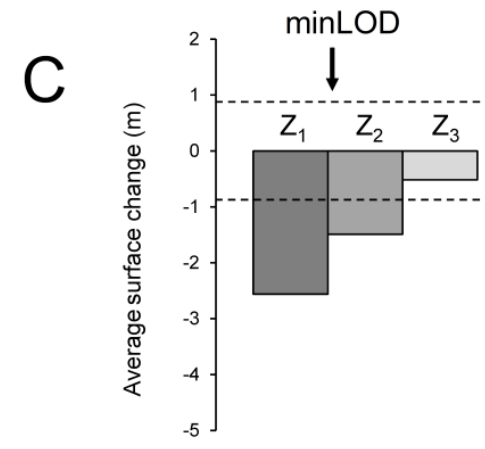

Figure 3 


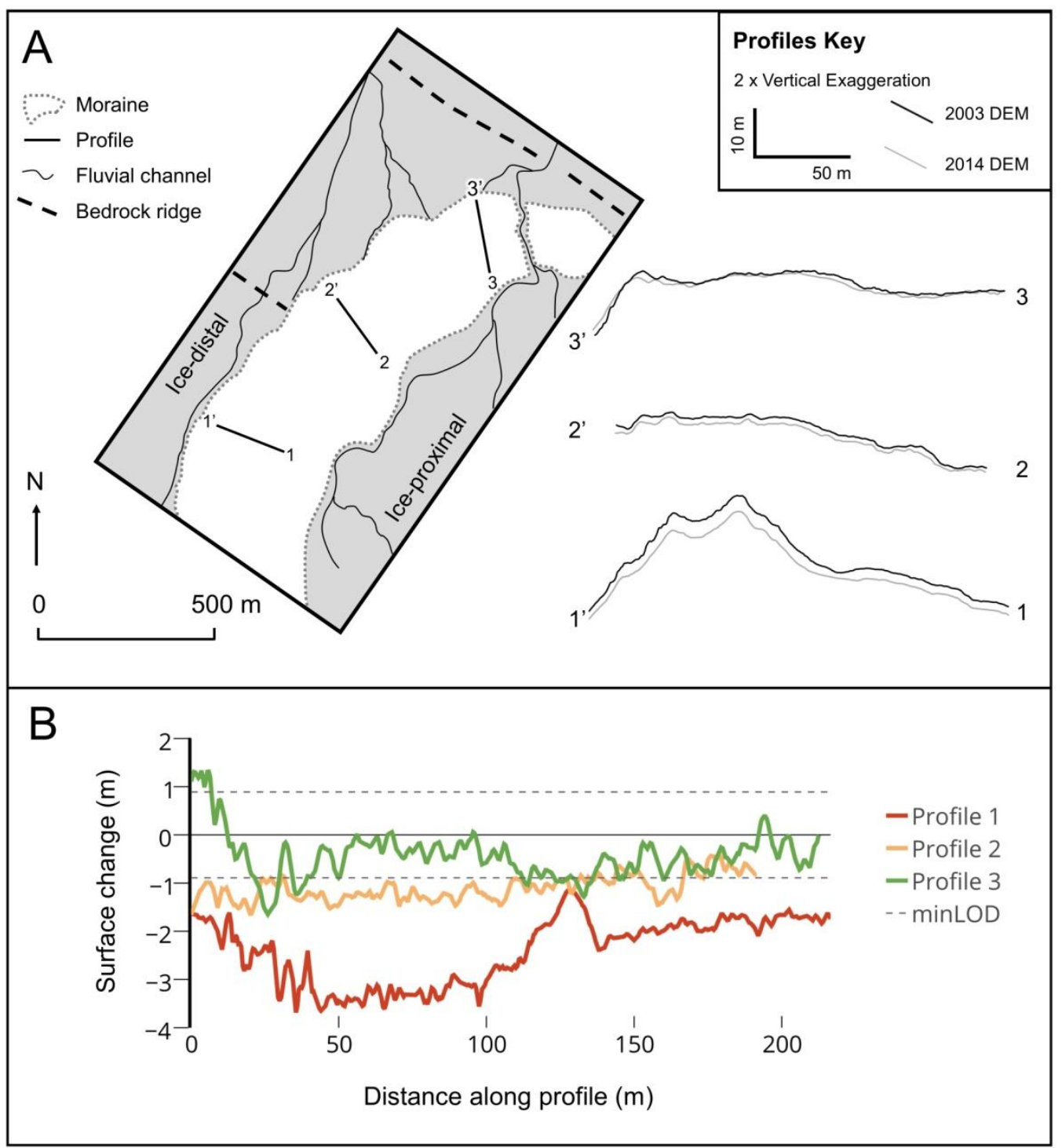

Figure 4 


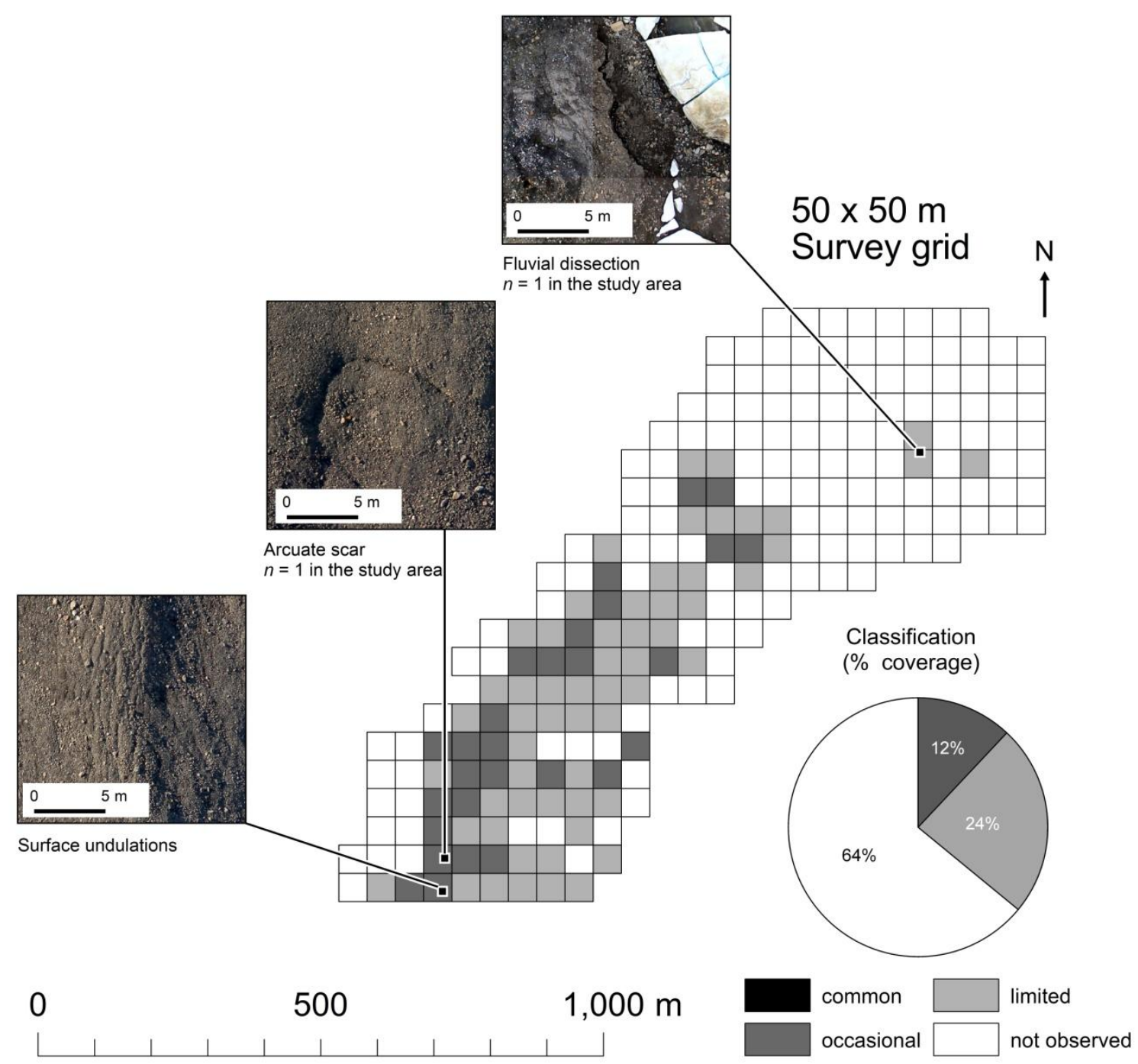

Figure 5 


\section{Present day} Inferred glacier surface (Neoglacial maximum)

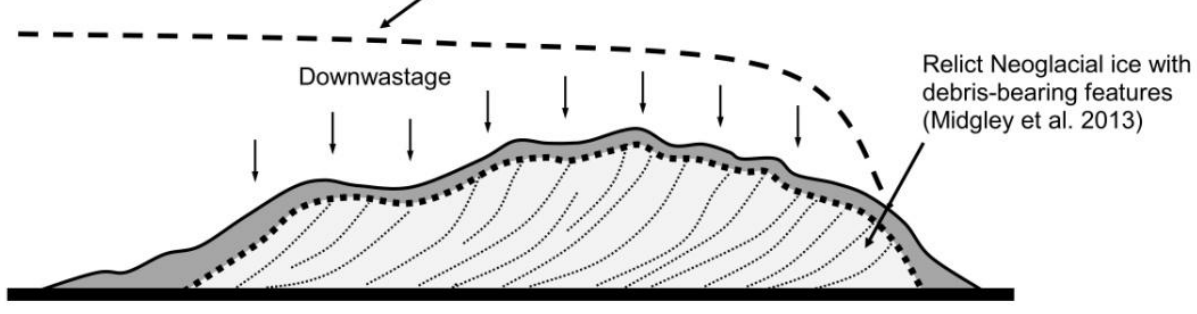

\section{End-point I: Partial de-icing}

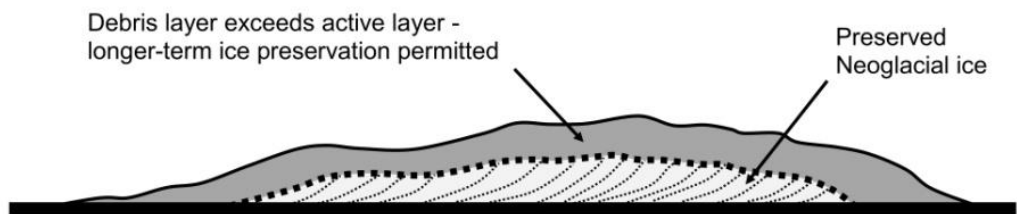

\section{End-point II: Complete de-icing}

Morphologically subdued deposit of gravel and diamicton

Figure 6 